\title{
Relief evolution of landslide slopes in the Kamienne Mts (Central Sudetes, Poland) - analysis of a high-resolution DEM from airborne LiDAR
}

\author{
Aleksandra Osika*, Małgorzata Wistuba, Ireneusz Malik \\ Faculty of Earth Sciences, University of Silesia in Katowice, Bedzinska 60, 41-200 Sosnowiec, Poland \\ * corresponding author: laleksandra.osika@gmail.com
}

Received: $5^{\text {th }}$ November, 2017

Accepted: $9^{\text {th }}$ January, 2018

\begin{abstract}
The aim of the study is to reconstruct the development of landslide relief in the Kamienne Mountains (Central Sudetes, SW Poland) based on a DEM from LiDAR data. Analyses of relief and geological maps in ArcGIS 10.5 and of slope cross-sections in Surfer 14 allowed to distinguish different types of landslide relief, developed in latites and trachybasalts lying above claystones and mudstones. The types vary from small, poorly visible landslides to vast landslides with complex relief. They were interpreted as consecutive stages of geomorphic evolution of hillslope-valley topography of the study area. Two main schemes have been established which explain the development of landslide slopes in the Kamienne Mts: (1) upslope, from the base of the slope towards the mountain ridge and (2) downslope, beginning on the top of the mountain ridge. The direction of landslide development depends on the thickness of volcanic rocks in relation to underlying sedimentary rocks. When the latter appear only in the lowest part of the slope, landslides develop upslope. If sedimentary rocks dominate on the slope and volcanic rocks form only its uppermost part, landslides develop downslope. The results show that landsliding leads to significant modifications of relief of the study area, including complete degradation of mountain ridges.
\end{abstract}

Key words: Landsliding, relief evolution, Kamienne Mountains, DEM, LiDAR

\section{Introduction}

Mass movements occur not only in high mountain areas (e.g. Cendrero and Dramis 1996; Guglielmi and Cappa 2010; Shroder Jr. et al. 2011; Pánek et al. 2017; Schwartz et al. 2017) but also in regions with lower topography (e.g. Wistuba et al. 2015; Yenes et al. 2015). Their importance for relief development can be significant and appear through developing new landforms and influencing other geomorphic processes, fluvial in particular (e.g. Cendrero and Dramis 1996; Korup et al. 2010). Korup et al. (2010) claim that landslides are the main source of sediments in the mountain areas. Vast landslides modify slope curvature and inclination, and take major part in reshaping catchment morphology. This may include even complete deformation of valley floors (Korup et al. 2010). To emphasise the role of landsliding as a formative process, Crozier (2010) proposed a term "landslide geomorphology system" in which "landslides are the dominative forms and process by governing the mechanisms, rhythm and pace of geomorphic change, in time and space". Geomorphological significance of landsliding was previously highlighted also by Cendrero and Dramis (1996). They indicated that in some cases, like the Canary Islands with vast landslides in volcanic rocks, landsliding may be the most important process in the topography evolution.

Despite potentially significant role of landsliding in moulding hillslope-valley 
systems, the process is often left unmentioned in theories of landscape evolution, not only in the earliest models (e.g. Davis 1899; Penck 1953; Klimaszewski 1967), but also in the later ones (e.g. Lavé and Avouac 2001; Kirby et al. 2003; Snyder et al. 2003; Clark et al. 2004). Moreover, according to Korup et al. (2010), it is a common view that the fluvial network controls the slope system, but the landsliding cannot influence fluvial processes. However, today mass movements are more and more often included in schemes of hillslope-valley systems development (e.g. Skempton 1953; Skempton and Delory 1957; Bisci et al. 1996; Brooks et al. 2002; Azañón et al. 2005; Lévy et al. 2012; Zerathe and Lebourg 2012; Migoń et al. 2013; Wistuba 2014; 2015), including research conducted in the Carpathian Mts, southern Poland (e.g. Starkel 1960; Ziętara 1974; Kotarba 1986; Gorczyca 2010; Gorczyca et al. 2014).

Today analyses of landslide relief and the role of landsliding in relief development can be facilitated by airborne LiDAR data. Highresolution DEMs from LiDAR data allow not only to identify individual forms, but also to determine their types of movement and to monitor landslide-affected areas (e.g. Jaboyedoff et al. 2012; Migoń et al. 2013, 2014b).

The study attempted to reconstruct the evolution of landslide slopes in a selected part of the Kamienne Mts by analysing their relief. In particular the study aimed to:

- distinguish different types of landslide slopes based on their relief characteristics: the degree of landslide development and subsequent reshaping, e.g. by linear erosion, slopewash, creep, particle fall and

- analyse relief of landslide-effected slopes in relation to bedrock.

We also tested the possibility to establish consecutive stages of relief evolution in the study area depending on geological conditions and geomorphological conditions, with the reservations about the reliability of the model based only on relief characteristics and the need for further, detailed studies to confirm potential findings.

\section{Study area}

The study area is located in the Kamienne Mts in the Central Sudetes, SW Poland (Fig. 1). Landslides in this area were described for the first time in the 1970s (Grocholski 1972; Pulinowa 1972; Pulinowa and Mazur 1971). The results of geomorphology mapping were presented by Synowiec (2003). Many papers describing arrangement, activity and types of movement of these landslides were published after 2010 (Kasprzak and Traczyk 2012; Migoń 2010; Migoń et al. 2010, 2014a-c). The significant role of landsliding in study area was proved by Kasprzak et al. (2016) who used LiDAR data to describe the case of a JeleniecRogowiec mountain ridge degraded by mass movements.

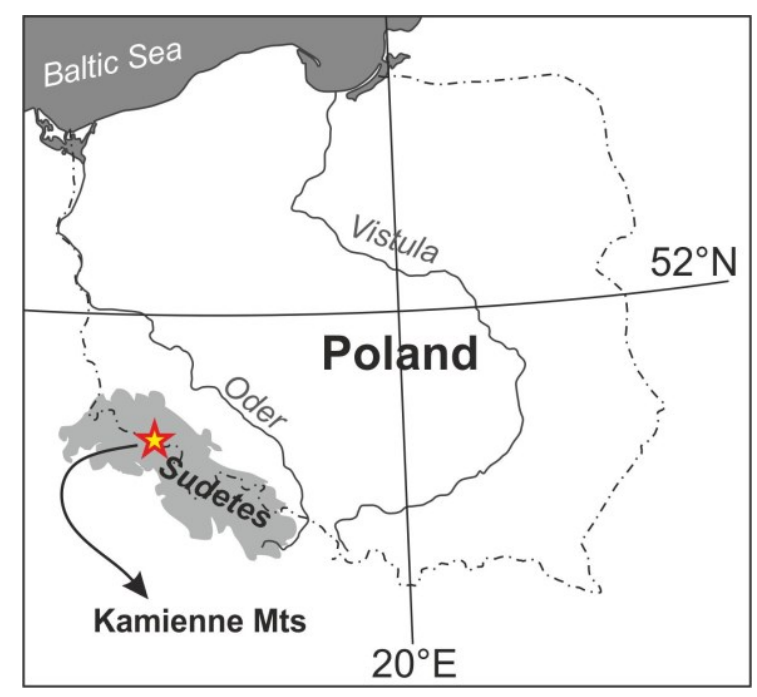

Fig.1. Location map of the study area in the Sudetes.

In this paper we have analysed the centraleastern part of the Kamienne Mts: the Suche Mts (Waligóra, $936 \mathrm{~m}$ a.s.l.) and Lesista Range (Lesista Wielka, $854 \mathrm{~m}$ a.s.1.). The bedrock of the Kamienne Mts consists of early Permian volcanic and subvolcanic rocks: rhyolite, latite, trachybasalts and tuff lying on sedimentary 
rocks: Carboniferous to early Permian claystones, mudstones, sandstones and conglomerates (Bossowski et al. 1995). In the study area mountain ridges are dissected by short, V-shaped or flat-bottomed valleys (Kasprzak and Traczyk 2012). Relief of the Kamienne Mts reflects contrast in erosion resistance of rocks, thus mountain ridges represent more resistant volcanic rocks and river valleys are incised into sedimentary rocks. Mean slope angles are $20-40^{\circ}$, but locally they exceed $60^{\circ}$ (Migoń et al. 2010). The climate of the Kamienne Mts is cool temperate (Migoń et al. 2014c). In the period 1977-2007 the mean annual temperature was $5.5^{\circ} \mathrm{C}$ and the mean annual precipitation was $776 \mathrm{~mm}$ at the nearby weather station in Mieroszów (500 m a.s.1.) (Migoń et al. 2014c).

\section{Materials and methods}

Analysis of landslides location and their extent was carried out using GIS software: ArcGIS 10.5 and Surfer 14. The studies were based on a high resolution DEM $(1 \mathrm{~m} \times 1 \mathrm{~m})$ from "Bare Earth" LiDAR data. The data were obtained from Central Office for Geodetic and Cartographic Documentation (CODGIK) in Poland. The scanning has been made in 20112014. The point density was 6 per $1 \mathrm{~m}^{2}$ and the maximum vertical error was $30 \mathrm{~cm}$. The data were obtained as *asc files and transformed into a point cloud. Then, DEM was used to prepare shaded relief maps (lighting azimuth $315^{\circ}$ and $135^{\circ}$ ) and slope maps (degrees) in ArcGIS 10.5 (Fig. 2). Each time data were classified with Natural Breaks (Jenks) method. The aforesaid maps were a basis for on screen digitalization of landslide areas using morphological criteria suggested by Dickau et al. (vide Migoń et al. 2014a):

- linear or arched scarps in the upper part of slopes,

- steep-alike arrangement of landslide blocks,

- hummocky, irregular relief of the lower parts of slopes,

- steep landslide toes and

- wide valley floors with irregular relief.

According to Migoń et al. (2014a), another important diagnostic feature is the contrast between varied landslide relief and smooth surface of surrounding inactive slopes. Landslides outlined in this study were divided into "distinct" (with clear relief) and "indistinct" (with unclear relief). Further detailed analysis of landslide topography was based on relief maps combined with scanned geological maps (1:25 000) in ArcGIS 10.5 (Fig. 3) and on 70 slope cross-sections in Surfer 14. This was a basis of classifying landslides according to their bedrock and distinguishing different types of landslide relief and then interpreting these types as consecutive stages of geomorphic evolution of relief in the study area (Figs. 4, 5).

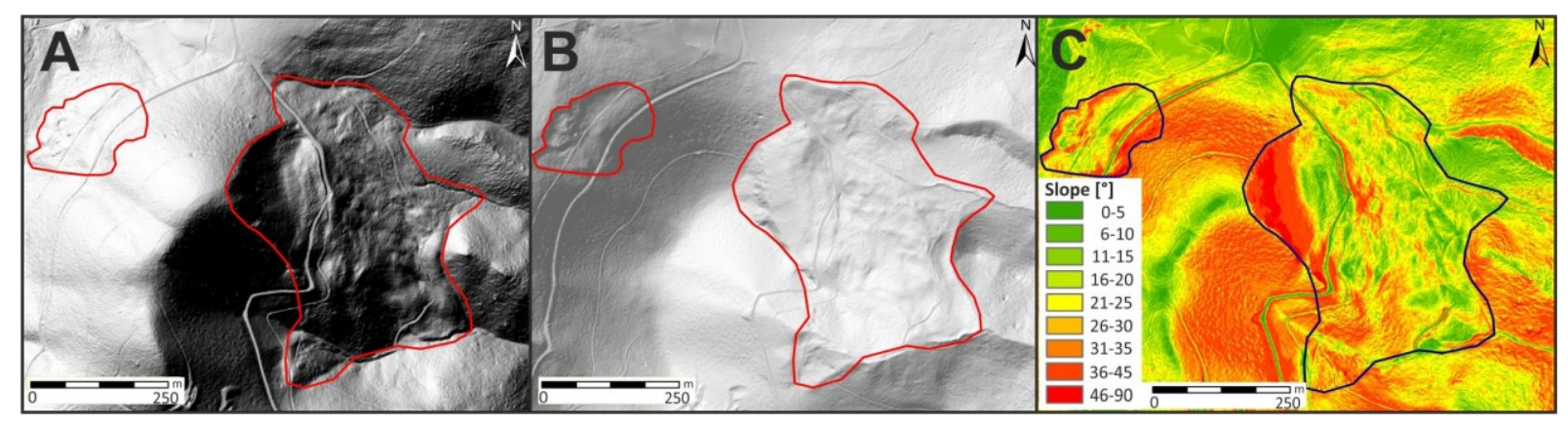

Fig.2. Example of landslide-affected slopes on shaded relief maps (A - standard $315^{\circ}$ lightning, B - $135^{\circ}$ lightning) and slope map (C) (DEM from airborne LiDAR). 


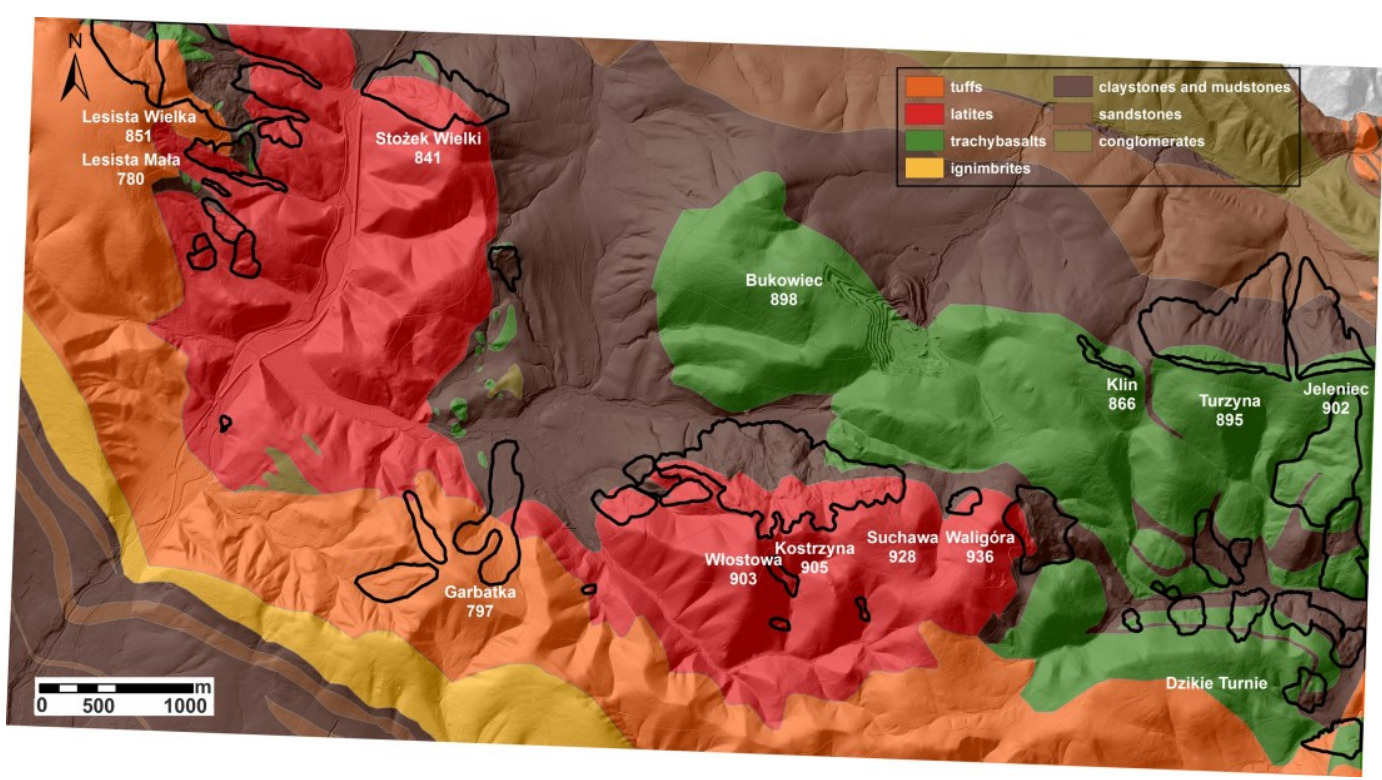

Fig.3. Bedrock of the study area and a shaded relief map from LiDAR data with landslide extent.
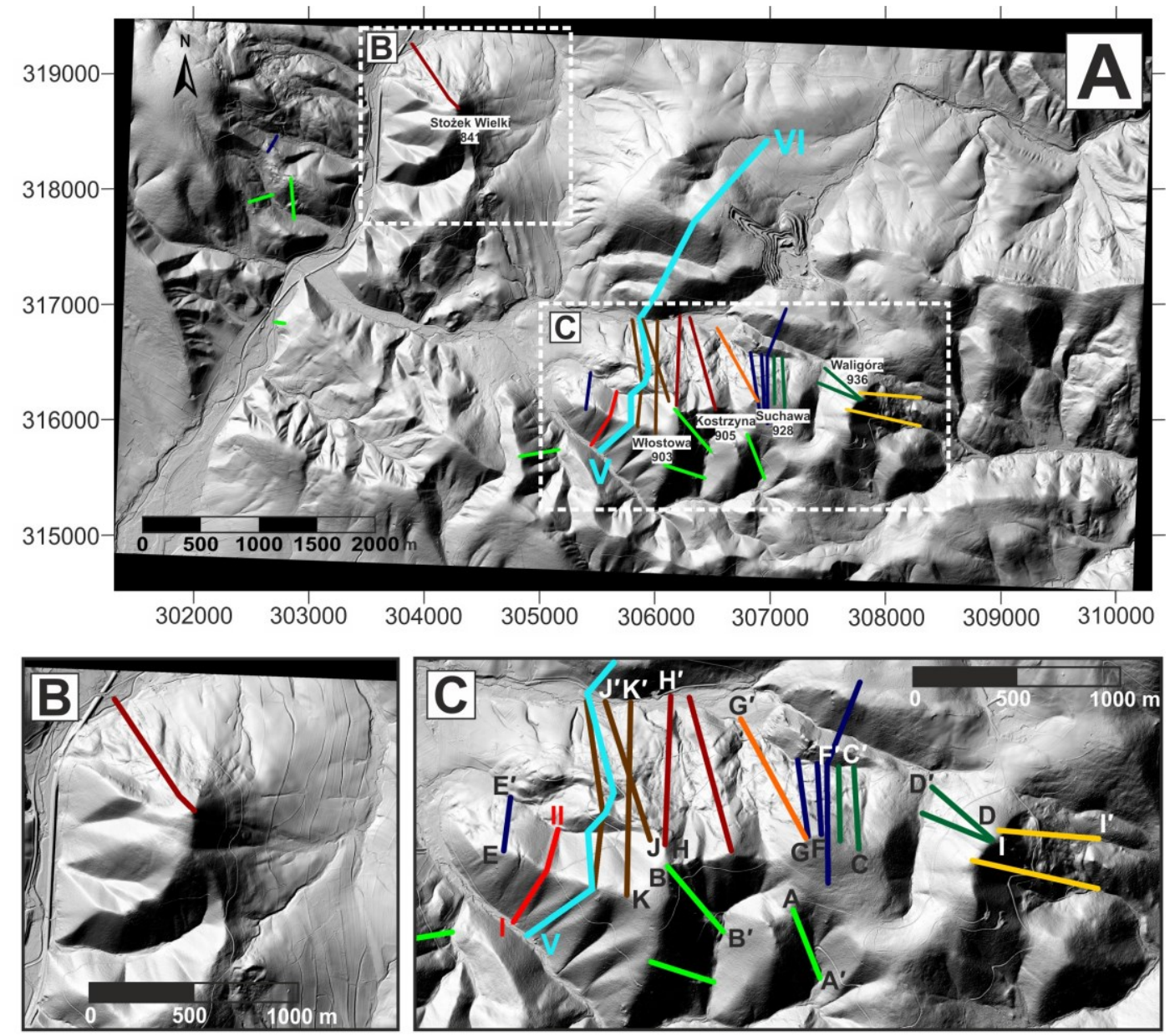

Reference slope -

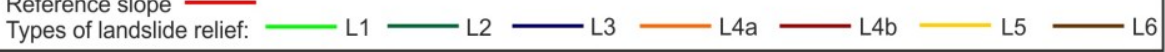

Fig.4. Distribution of slope cross sections representing types of landslide relief in latites. Each color of cross sections lines marks a different type of landslide relief (L1-L6) (cross sections: Fig. 7). 

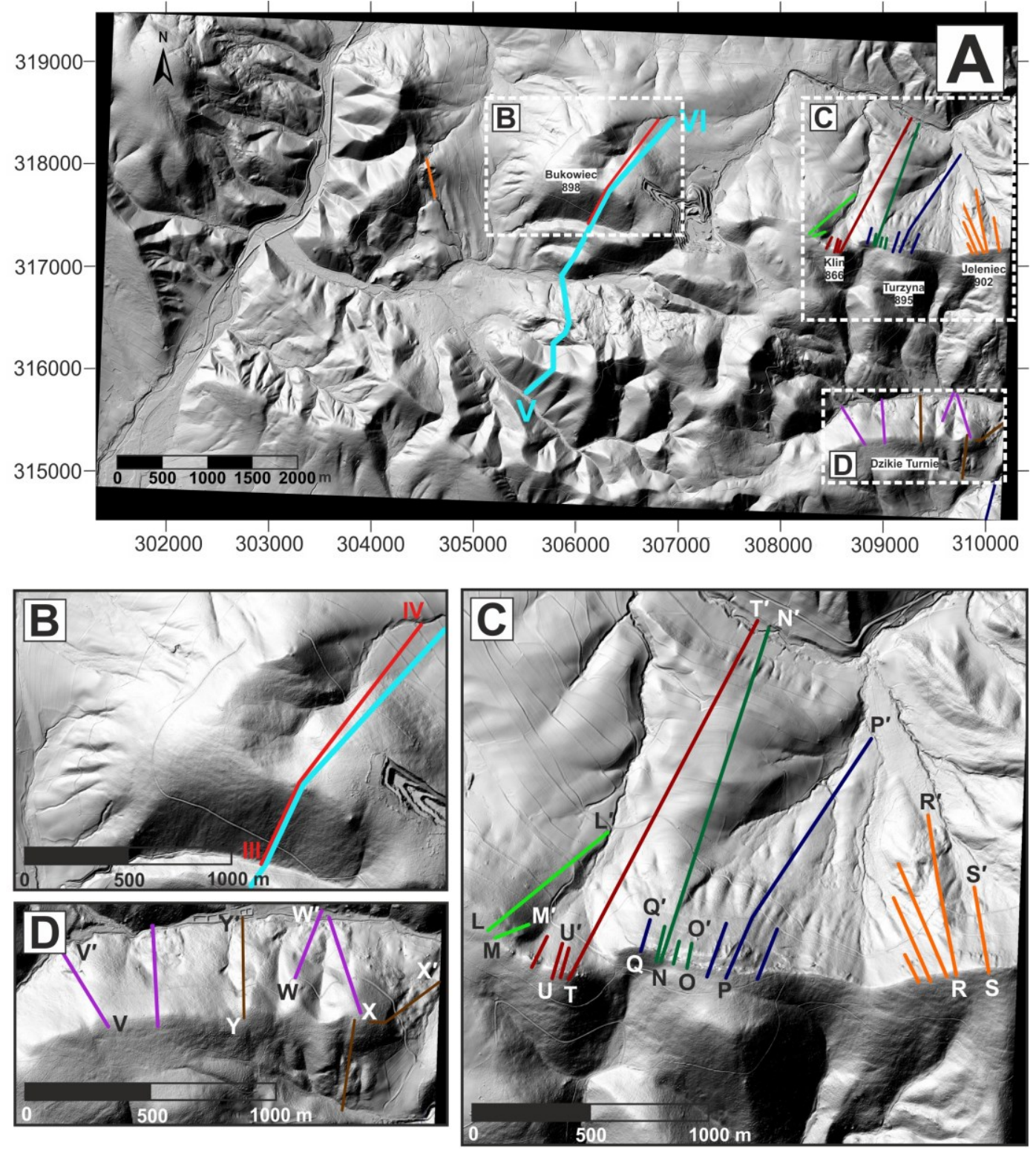

Reference slope -

Fig.5. Distribution of slope cross sections representing types of landslide relief in trachybasalts. Each color of cross sections lines marks a different type of landslide relief (B1-B7) (cross sections: Fig. 8).

\section{Results}

General features of landslide relief of the study area

Analysed part of the Kamienne Mts covers $34.46 \mathrm{~km}^{2}$ including $3.93 \mathrm{~km}^{2}$ of landslide relief (11.4\% of the study area). Analysis of shaded relief maps and slope maps allowed us to distinguish 40 landslides (Fig. 3). Three of them are vast landslide slopes $\left(0.46-0.64 \mathrm{~km}^{2}\right)$ with complex relief. The mean landslide rate (amount of landslides per area unit) is 1.16 per $1 \mathrm{~km}^{2}$ and the mean landslide area is $0.10 \mathrm{~km}^{2}$. Detailed analysis of landslide arrangement in relation to geology of the Kamienne Mts allowed to distinguish three groups of landslides, based on types of rocks in which the main scarps developed: latites, trachybasalts and tuffs (Fig. 6).

Almost three quarters of landslides in the study area ( $71 \%$ of landslide-effected areas) 
occur on the northern, north-eastern and northwestern slopes. Only $11 \%$ of landslides developed on the southern slopes and $2 \%$ on south-eastern slopes (Fig. 6). The analysis of landslide distribution in relation to the geology of Kamienne Mts has shown that landslides developed in latites generally occurs on the northern slopes. Landslides developed in trachybasalts occurs on both northern and southern slopes. The former are, however, more extensive and have more complex relief of the landslide body. Landslides developed in tuffs usually occurs on northern or northeastern slopes. Irrespective of the bedrock, landslides on the northern and eastern slopes are generally more extensive and have more complex relief.

\section{Types of landslide relief distinguished based on LiDAR data}

Slope cross sections allowed to distinguish different types of landslide relief present in the study area (Figs. 7, 8). For landslides developed in latites (L types) these features include: total length and location on the slope, relief characteristic of the main scarp, crown cracks, fragmentation of the landslide body, presence of minor scarps and a scree from secondary particle fall (Table 1.). For landslides developed in trachybasalts (B types) these features include: location on the slope, relief characteristic of the main scarp, trench, fragmentation of the landslide body and presence of a minor scarps (Table 2.). The criteria of the performed classifications are not the same for L and B types due to significant differences in their relief. For each type we have performed the classification using the most diagnostic relief features, i.e. the most differing features of relief within each type. The types of landslide relief were outlined in relation to reference slopes not affected by landsliding. In the study area these stable slopes are steep $\left(20-30^{\circ}\right)$, straight or convex and have smooth surface (Fig. 7 I-II, Fig. 8 III-
IV). Landslides developed in tuffs have been omitted in further analysis as there are only few of them (5).

The L1 type of landslide relief developed in latites is represented by small, poorly developed landslides in the lower part of slopes with indistinct head scarps and distinct, single toes (Figs. 4, 7 A-A', B-B'). As opposed to the other types, this landslides are very shallow and occur on slopes that consists only of volcanic rocks. Other types of landslides developed in the latites (L1-L6) were distinguished on slopes where sedimentary rocks occur at the contact with valley floor. The L2 type refers to small landslides with poorly developed head scarps in the lower part of slopes and distinct toes (Figs. 4, 7 C-C', D$\left.\mathrm{D}^{\prime}\right)$. The $\mathrm{L} 3$ type of landslides have clear, steep head scarps in the middle part of slopes and complex relief of the landslide body (Figs. 4, 7 E-E', F-F'). The L4 type are vast landslides with steep, high head scarp in the upper part of the slope and complex relief of the landslide body. The L4 type of landslides were additionally divided into two subtypes: L4a vast landslides with fresh relief, very steep and high head scarps in the uppermost part of the slopes, crown cracks, trenches and active scree (Figs. 4, 7 G-G'), and L4b - vast landslides with less distinct relief, steep and high head scarps in the uppermost part of the slopes and with complex relief of the landslide body (Figs. 4, 7 F-F'). Finally, vast landslides of the L5 type have head scarps reaching the topographic culmination of a mountain ridge (Figs. 4, 7 I-I'), while landslides of the L6 type have head scarps which have exceeded mountain ridges and affected the backslopes (Figs. 4, 7 J-J', K-K').

The B1-B5 types developed on slopes where trachybasalts form only a thin cap over a slope composed of sedimentary rocks (Fig. 3). The B1 type of landslide relief refers to poorly developed, shallow trenches in the uppermost parts of slopes with smooth, undisturbed surface below (Figs. 5, 8 L-L', M-M'). The B2 
type are clearly visible, widened trenches in the uppermost parts of slopes with undulating, disturbed surface below (shallow, elongated depressions and low ridges parallel to slope inclination) (Figs. 5, 8 N-N', O-O'). The B3 type refers to distinctly slided single colluvial blocks with similar ridges and hollows as previously mentioned (Figs. 5, 8 P-P', Q-Q'). Landslides of the B4 type are vast and have steep head scarps, reshaped by successive events of landsliding (Figs. 5, 8 R-R', S-S'). Then, the B5 type refers to small, poorly visible scarps with shallow colluvial blocks below (Figs. 5, 8 T-T', U-U'). Landslides of the B6 and B7 types have different topography compared to the previous five types and developed in slopes of different bedrock where trachybasalts predominated over underlying sedimentary rocks. The B6 type are landslides with head scarps in the lower part of slopes, similar to landslides of the L2 type in latites (Figs. 5, 8 V-V', W-W'; Figs. 4, 7 C-C', D-D'). The B7 type are landslides with head scarps in the upper part of slopes, similar to the L5 type (Figs. 5, 8 X-X', Y-Y; Figs. 4, 7 I-I').

\section{Established schemes of landslide relief development in the Kamienne Mts}

Presented above detailed analysis of the types of landslide slopes in the study area allowed us to establish consecutive stages of their development. We have established the two main schemes of the evolution of landslide slopes, based on its up- and downslope direction (Figs. 9, 10).

\section{Upslope scheme of landslide relief evolution}

Landslide evolution in the upslope scheme begins in the lower part of the slope, next landslides expand upslope. The scheme is represented by the following, earlier established in the study area, types of landslide relief (Fig. 9):

- stable slope, not affected by landsliding,
- small landslides with poorly developed head scarps in the lower part of slopes and distinct toes (L2 and B6 types),

- landslides with clear, steep head scarps in the middle part of slopes and complex relief of the landslide body (L3 type),

- vast landslides with high, steep head scarps in the upper part of slopes, complex relief of the landslide body and screes (L4 type),

- vast landslides with head scarps reaching the topographic culmination of the mountain ridge (L5 and B7 types),

- landslides with head scarps exceeding the topographic culmination of the mountain ridge (L6 type).

The scheme was based on landslide relief found in Włostowa - Kostrzyna - Suchawa Waligóra range and on slopes of Dzikie Turnie and Stożek Wielki (Figs. 4, 5). Landsliding starts in the lower part of a slope, near the geological boundary between volcanic (latites or trachybasalts) and sedimentary rocks (claystones and mudstones) (Fig. 9a). The scheme occurs regardless of the type of volcanic rocks in which the head scarp developed. The necessary condition is considerable thickness of volcanic rocks in relation to underlying sedimentary rocks in the base of slopes (Fig. 7 L2-L6, Fig. 8 B6-B7). The slopes are generally stable when they consist only of volcanic rocks. Very few, shallow landslides occur in such cases (L1 type). Significant landslide activity begins when fluvial erosion dissects volcanic rocks and exposes weak, plastic sedimentary rocks at the base of slopes. Then first landslides develop near the valley floor (L2 and B6 types, Fig. 9a). This process undermines the slope at its basis and makes its upper part unstable. The first event of landsliding promotes further instability of the slope and causes successive landslides. The headscarp migrates upslope in consecutive events of landsliding and the landslide expands upward. In the following stages (L3-L4 types) the height and inclination of headscarps increase (Fig. 9 b-c). Then, 
particle fall and rockfalls lead to reshaping and retreat of headscarp (now a rock wall) and to covering landslide bodies with screes (L4 type). In the next stage head scarps reach the topographic culmination of the mountain ridge (L5 type) (Fig. 9d). While landsliding continues to expand into disturbed mountain ridge the head scarp exceeds the topographic culmination of the mountain ridge (L6 type) (Fig. 9e). Such case have been found on the northern slope of Włostowa Mt, where landsliding have led to almost complete degradation of the mountain ridge (Figs. 7, $9 \mathrm{~J}$ $\left.\mathrm{J}^{\prime}, \mathrm{K}-\mathrm{K}^{\prime}\right)$.

\section{Downslope scheme of landslide relief evolution}

Landslide evolution in the downslope model begins at the top of the mountain ridge, next landslides expand downslope. The scheme is represented by the following, earlier established in the study area, types of landslide relief (Fig. 10):

- stable slope, not affected by landsliding, - poorly developed, shallow trench in the uppermost parts of the slope with smooth, undisturbed surface below (B1 type),
- clearly visible, widened trenches in the uppermost parts of slopes with undulating, disturbed surface below (shallow, elongated depressions and low ridges parallel to slope inclination (B2 type),

- distinctly slided single colluvial blocks with undulating, disturbed surface below (shallow, elongated depressions and low ridges parallel to slope inclination) (B3 type),

- vast landslides with steep head scarps reshaped by successive events of landsliding (B4 type),

- small, poorly visible scarps with shallow colluvial blocks below (B5 type).

The scheme was based on landslide relief found in Klin - Turzyna - Jeleniec range (Fig. 5). In this model landsliding is also initiated near the boundary between volcanic (trachybasalts) and sedimentary rocks (claystones and mudstones) which, however, is located in the upper part of a slope (Fig. 10a). This scheme takes place on slopes which consists mainly of sedimentary rocks covered by a thin cap of volcanic rocks. At first, a shallow trench occurs within trachybasalts at the top of a mountain ridge while the rest part of the slope has smooth, undisturbed surface (B1 type) (Fig. 10a). While the landslide

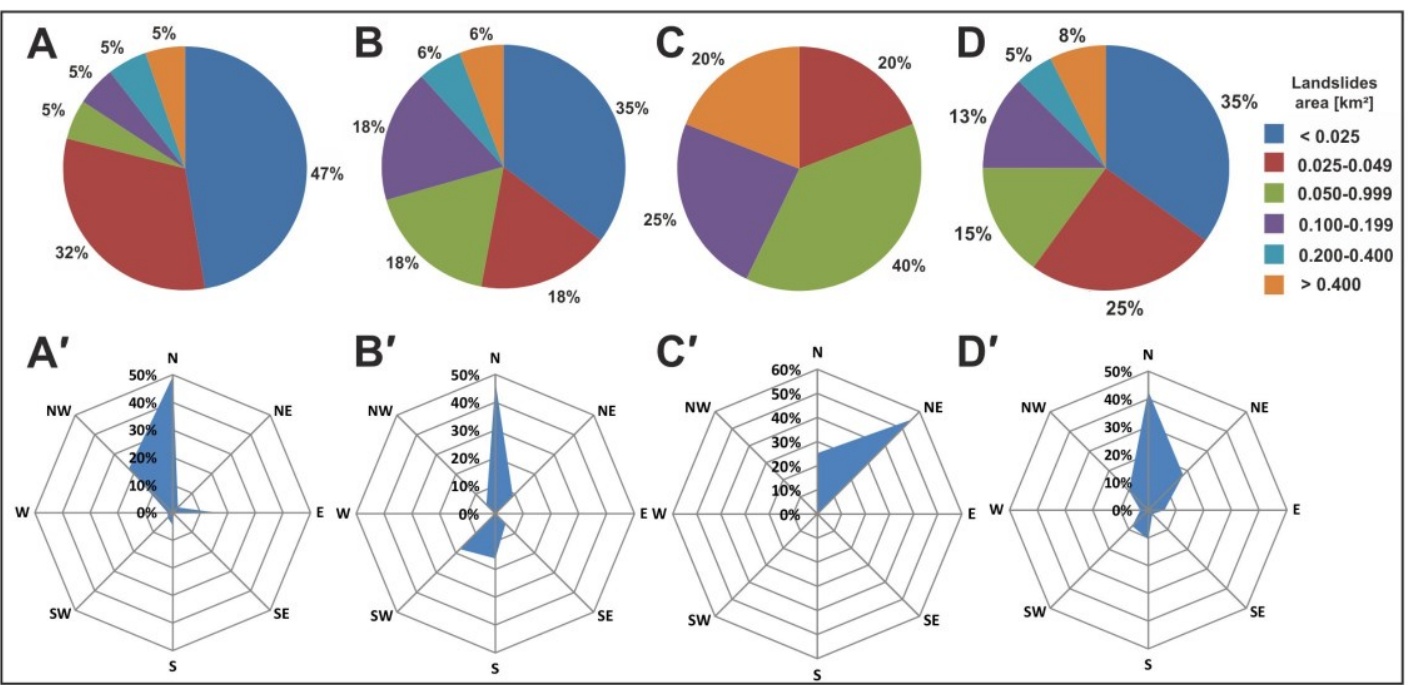

Fig.6. Diversity of landslides area in latites (A), trachybasalts (B), tuffs (C), in general (D), and exposure of landslide-effected areas in latites $\left(\mathrm{A}^{\prime}\right)$, trachybasalts $\left(\mathrm{B}^{\prime}\right)$, tuffs $\left(\mathrm{C}^{\prime}\right)$, and in general $\left(\mathrm{D}^{\prime}\right)$. 


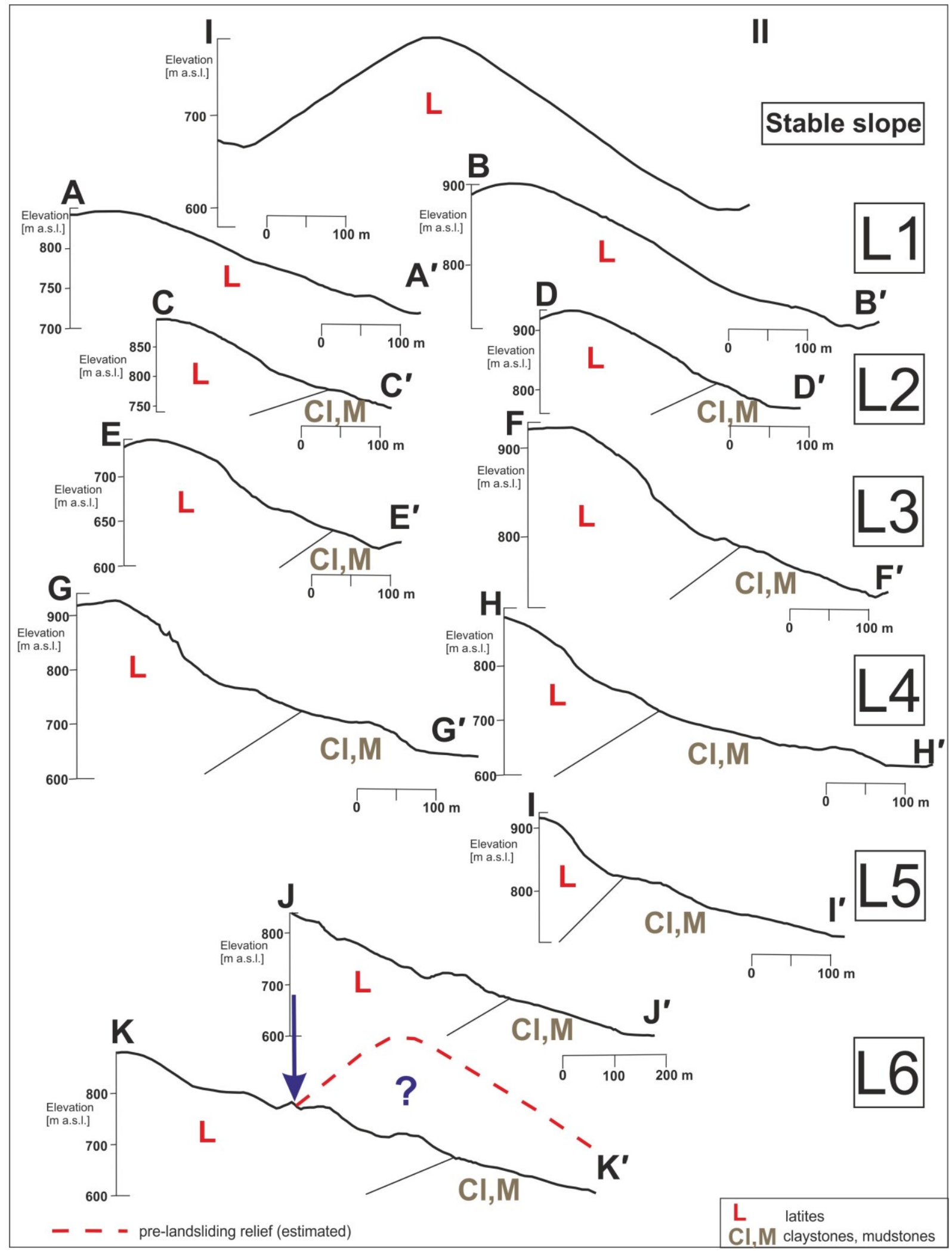

Fig.7. Cross sections of a stable (I-II) and landslide slopes (A-A', B-B' ...) representing types of relief developed in latites. Arrow indicate enlarged cross sections of a particular slope. 


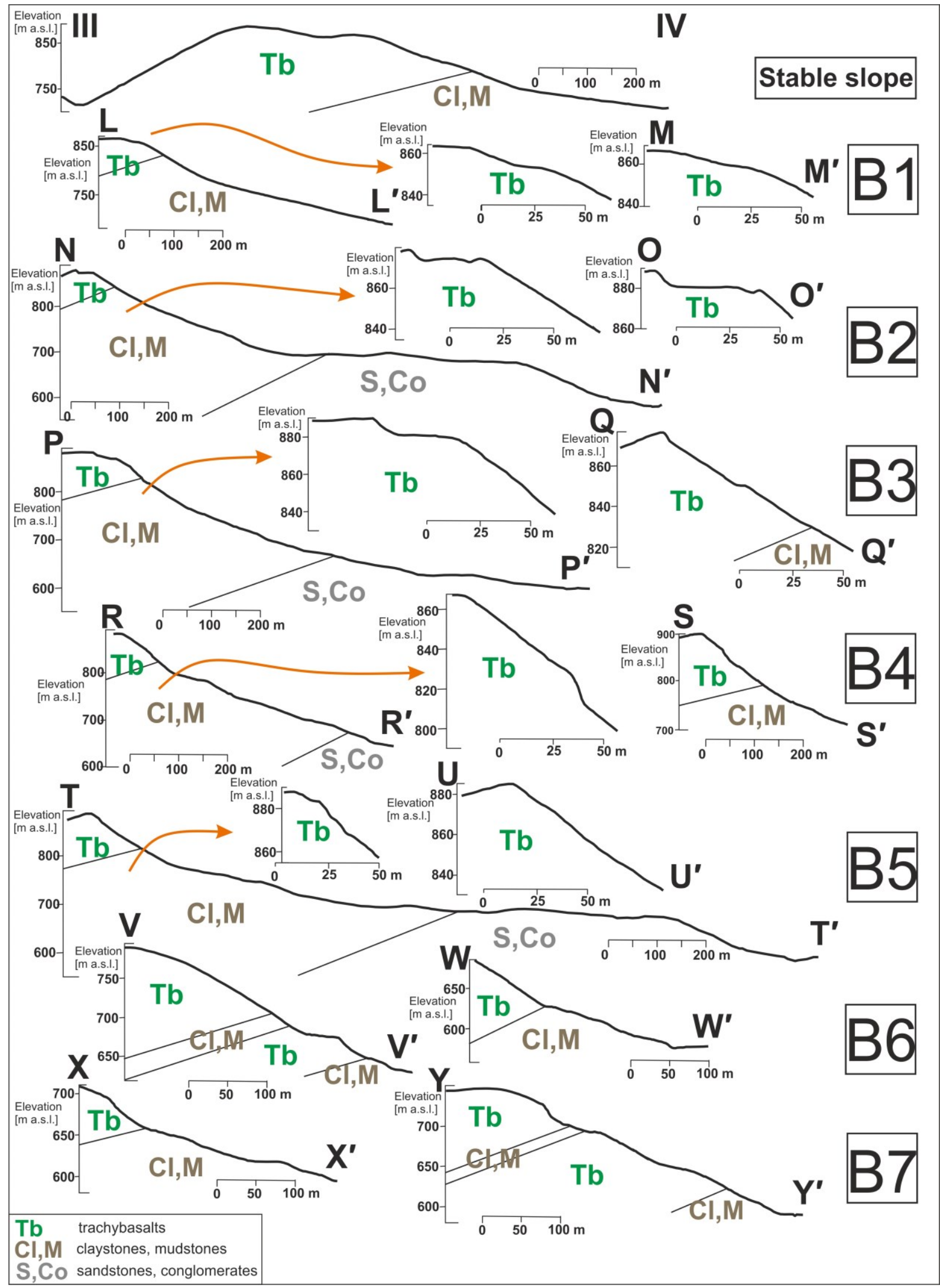

Fig.8. Cross sections of a stable (III-IV) and landslide slopes (L-L', M-M'...) representing types of relief developed in trachybasalts. Arrows indicate enlarged cross sections of particular slopes. 


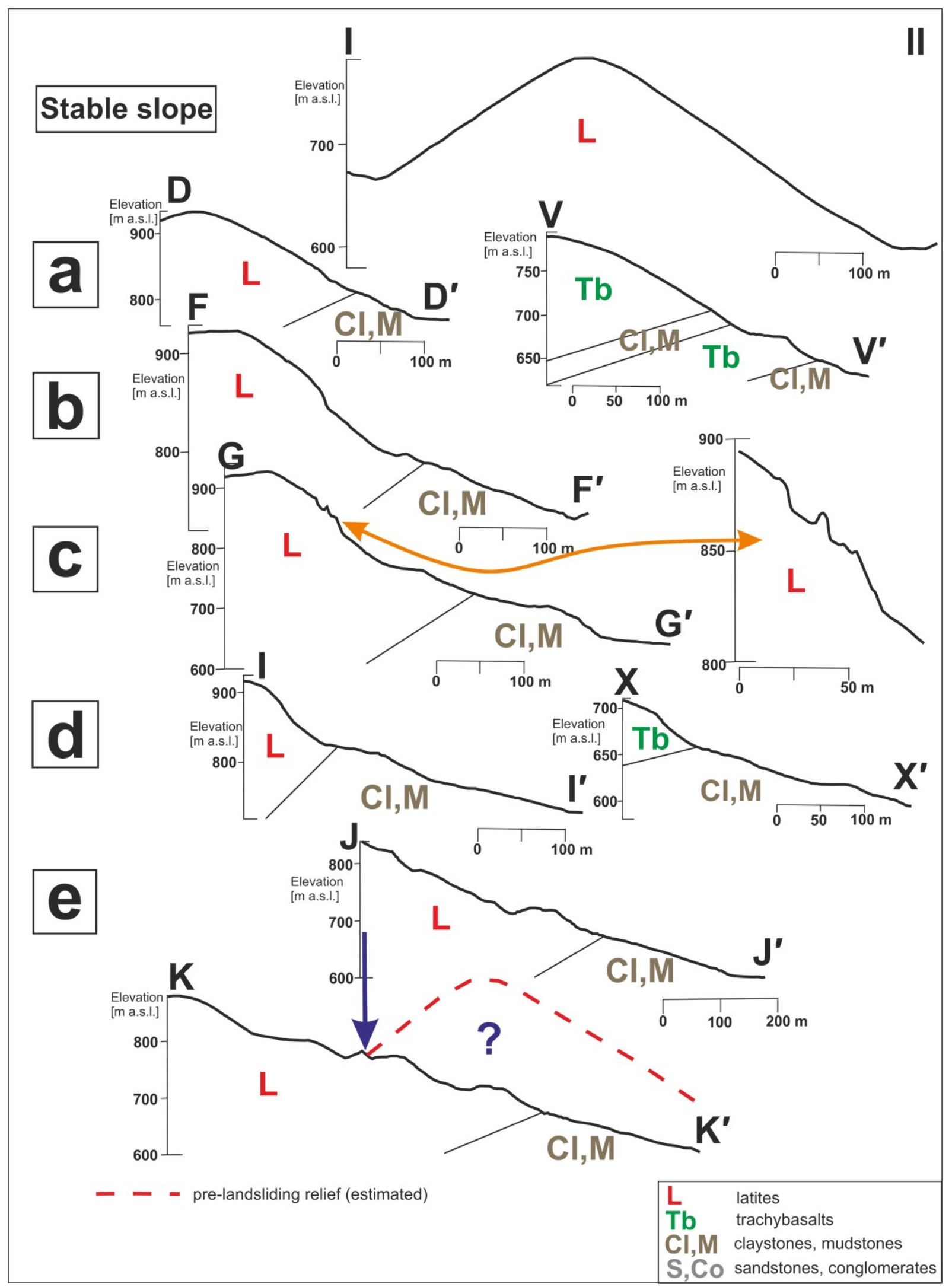

Fig.9. A scheme of upslope landslide evolution. Letters a-e stand for consecutive stages of landslides development. Arrows indicate enlarged cross sections of particular slopes. Profile descriptions (e.g. D-D', I-II) indicate their location in the field (see Figs. 4-5). 


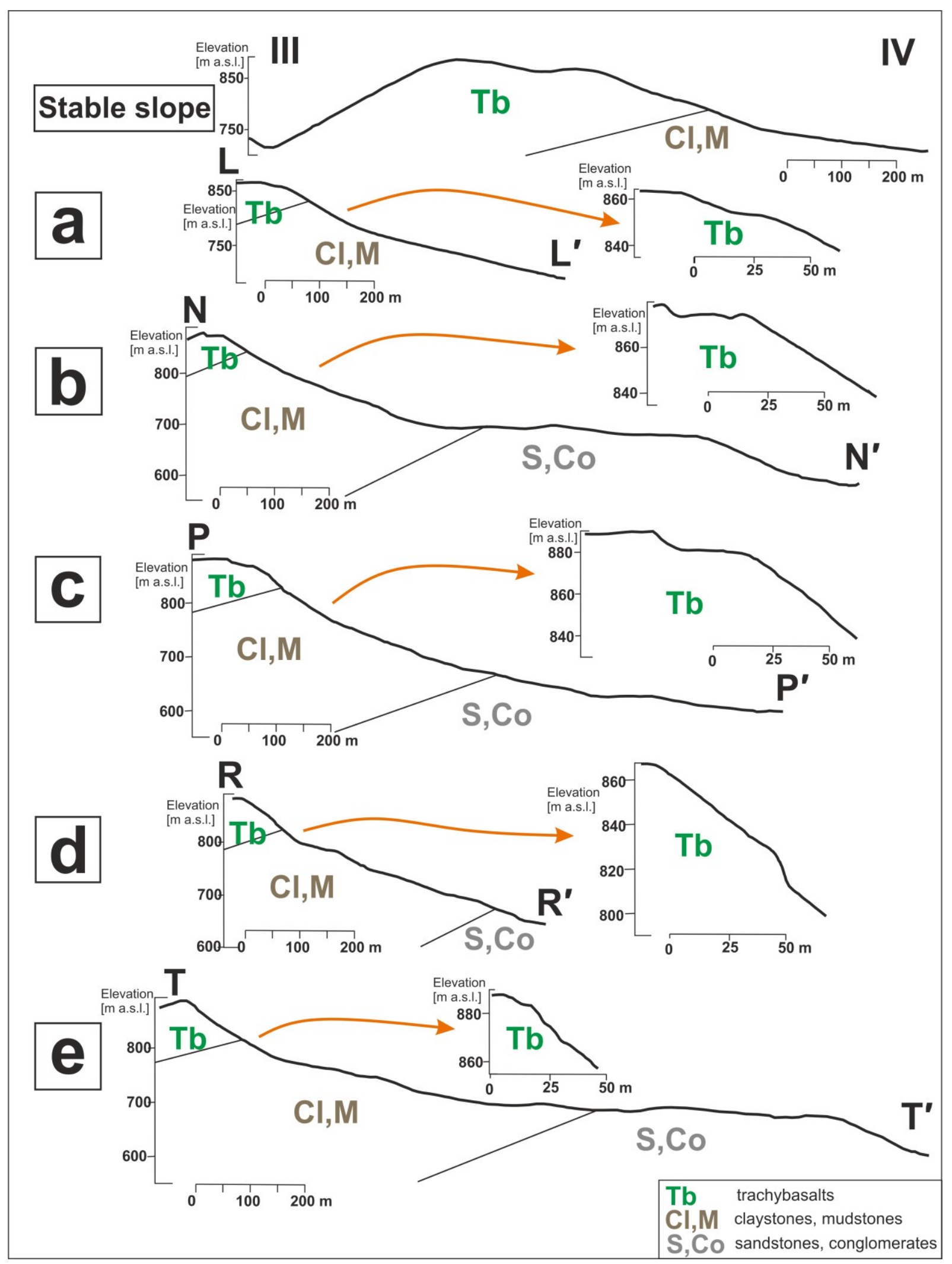

Fig.10. A scheme of downslope landslide evolution. Letters a-e stand for consecutive stages of landslides development. Arrows indicate enlarged cross sections of particular slopes. Profile descriptions (e.g. L-L', III-IV) indicate their location in the field (see Figs. 4-5). 
Tab.1. Types of relief and diagnostic features of landslides developed in latites.

\begin{tabular}{|c|c|c|c|c|c|c|c|c|c|}
\hline $\begin{array}{l}\text { Types of relief } \\
\text { Diagnostic features }\end{array}$ & \begin{tabular}{|l|} 
Number of \\
analysed slope \\
profiles \\
representing \\
each type
\end{tabular} & Area $\left[\mathrm{km}^{2}\right]$ & Total length $[\mathrm{m}]$ & $\begin{array}{l}\text { Location on the } \\
\text { slope }\end{array}$ & $\begin{array}{l}\text { Relief characteristic of the main } \\
\text { scarp }\end{array}$ & $\begin{array}{l}\text { Crown } \\
\text { cracks }\end{array}$ & Fragmentation of the landslide body & $\begin{array}{l}\text { Minor } \\
\text { scarps }\end{array}$ & Scree \\
\hline $\begin{array}{l}\text { L1 - small, poorly developed landslides in the lower part } \\
\text { of slopes with indistinct head scarps and distinct, single } \\
\text { toes }\end{array}$ & 7 & $0.004-0.038$ & $60-300$ & Lower part & Poorly developed, very low & & Single toe with regular relief & & \\
\hline $\begin{array}{l}\text { L2 - small landslides with poorly developed head scarps } \\
\text { in the lower part of slopes and distinct toes }\end{array}$ & 4 & $0.025-0.045$ & $150-250$ & Lower part & Poorly developed, low (15-20 m) & & Irregular, undulant relief, distinct toe & & \\
\hline $\begin{array}{l}\text { L3 - landslides with clear, steep head scarps in the middle } \\
\text { part of slopes and complex relief of the landslide body }\end{array}$ & 5 & $0.006-0.040$ & $42-304$ & Middle-lower part & $\begin{array}{l}\text { Distinct, medium high }(20 \mathrm{~m}) \\
\text { steep (to } 65^{\circ} \text { ) }\end{array}$ & & Transverse slid blocks, indistinct toe & + & \\
\hline $\begin{array}{l}\text { L4a - vast landslides with fresh relief, very steep and high } \\
\text { head scarps in the uppermost part of the slopes, crown } \\
\text { cracks, trenches and active screes }\end{array}$ & 1 & \multirow{2}{*}{$0.090-0.250$} & \multirow{2}{*}{$489-678$} & Upper-lower part & $\begin{array}{l}\text { High (to } 30 \mathrm{~m} \text { ), steep (to } 75^{\circ} \text { ), } \\
\text { rock wall }\end{array}$ & + & Distinct transverse slid blocks & + & + \\
\hline $\begin{array}{l}\text { L4b - vast landslides with less distinct relief, steep and } \\
\text { high head scarps in the uppermost part of the slopes and } \\
\text { with complex relief of the landslide body }\end{array}$ & 3 & & & Upper-lower part & $\begin{array}{l}\text { High (to } 25 \mathrm{~m} \text { ), steep (to } 60^{\circ} \text { ), } \\
\text { rock wall }\end{array}$ & & $\begin{array}{l}\text { Transverse slid blocks, hummocky } \\
\text { topography, erosional incisions }\end{array}$ & + & + \\
\hline $\begin{array}{l}\text { L5 - vast landslides with head scarps reaching the } \\
\text { topographic culmination of a mountain ridge }\end{array}$ & 2 & 0.164 & 500 & $\begin{array}{l}\text { Whole slope from } \\
\text { the mountain ridge } \\
\text { to the slope base }\end{array}$ & High (to $25 \mathrm{~m}$ ), steep (to $50^{\circ}$ ) & & $\begin{array}{l}\text { Transverse slid blocks, hummocky } \\
\text { topography, erosional incisions, indistinct } \\
\text { toe }\end{array}$ & + & \\
\hline $\begin{array}{l}\text { L6 - vast landslides with head scarps exceeding the } \\
\text { topographic culmination of a mountain ridge }\end{array}$ & 3 & 0.196 & 615 & $\begin{array}{l}\text { Whole mountain } \\
\text { ridge (including the } \\
\text { opposite slope) }\end{array}$ & $\begin{array}{l}\text { Medium high }(15-25 \mathrm{~m}) \text {, steep } \\
\left(40-60^{\circ}\right)\end{array}$ & & $\begin{array}{l}\text { Distinct transverse slid blocks, mid-slope } \\
\text { depression, irregular, indistinct relief with } \\
\text { erosional incisions in the lower part of the } \\
\text { landslide body }\end{array}$ & + & \\
\hline
\end{tabular}


Tab.2. Types of relief and diagnostic features of landslides developed in trachybasalts.

\begin{tabular}{|c|c|c|c|c|c|c|}
\hline Types of relief & \begin{tabular}{|l|} 
Number of \\
analysed slope \\
profiles \\
representing \\
each type
\end{tabular} & Location on the slope & $\begin{array}{l}\text { Relief characteristic of the } \\
\text { main scarp }\end{array}$ & Trench & $\begin{array}{l}\text { Fragmentation of the } \\
\text { landslide body }\end{array}$ & Minor scarps \\
\hline $\begin{array}{l}\text { B1 - poorly developed, shallow trenches in the uppermost } \\
\text { parts of the slopes with smooth, undisturbed surface } \\
\text { below }\end{array}$ & 2 & Top of the mountain ridge & Indistinct & $\begin{array}{l}\text { Poorly developed, shallow } \\
(7 \mathrm{~m}), 35 \mathrm{~m} \text { wide }\end{array}$ & $\begin{array}{l}\text { Smooth, undisturbed } \\
\text { surface }\end{array}$ & \\
\hline $\begin{array}{l}\text { B2 - clearly visible, widened trenches in the uppermost } \\
\text { parts of the slopes with undulating, disturbed surface } \\
\text { below (shallow, elongated depressions and low ridges } \\
\text { parallel to slope inclination) }\end{array}$ & 4 & $\begin{array}{l}\text { Top of the mountain ridge-upper } \\
\text { part of the slope }\end{array}$ & Low $(<10 \mathrm{~m})$, steep & $\begin{array}{l}\text { Clearly visible, widened to } \\
\text { a rock bench }(20-60 \mathrm{~m} \\
\text { wide) }\end{array}$ & $\begin{array}{l}\text { Low ridges and shallow, } \\
\text { elongated depressions } \\
\text { parallel to slope } \\
\text { inclination }\end{array}$ & \\
\hline $\begin{array}{l}\text { B3 - distinctly slided single colluvial blocks with } \\
\text { undulating, disturbed surface below (shallow, elongated } \\
\text { depressions and low ridges parallel to slope inclination) }\end{array}$ & 5 & $\begin{array}{l}\text { Top of the mountain ridge-upper } \\
\text { part of the slope }\end{array}$ & Medium-high (>20 m), steep & & $\begin{array}{l}\text { Low ridges and shallow, } \\
\text { elongated depressions } \\
\text { parallel to slope } \\
\text { inclination, slided single } \\
\text { colluvial block below }\end{array}$ & \\
\hline $\begin{array}{l}\text { B4 - vast landslides with steep head scarps reshaped by } \\
\text { successive events of landsliding }\end{array}$ & 6 & $\begin{array}{l}\text { Whole slope from the mountain } \\
\text { ridge to the slope base }\end{array}$ & Medium-high $(>20 \mathrm{~m}$ ), steep & & $\begin{array}{l}\text { Hummocky topography } \\
\text { with distinct subsequent } \\
\text { colluvia }\end{array}$ & \\
\hline $\begin{array}{l}\text { B5 - small, poorly visible scarps with shallow colluvial } \\
\text { blocks below }\end{array}$ & 4 & Top of the mountain ridge & Indistinct, low & & Shallow colluvial blocks & \\
\hline $\begin{array}{l}\text { B6 - landslides with head scarps in the lower part of the } \\
\text { slopes and distinct transverse slid blocks below }\end{array}$ & 4 & Middle-lower part & $\begin{array}{l}\text { Medium-high (15-25 m), } \\
\text { steep }\end{array}$ & & $\begin{array}{l}\text { Transverse slid blocks, } \\
\text { irregular, hummocky } \\
\text { topography, distinct toes }\end{array}$ & + \\
\hline $\begin{array}{l}\text { B7 - landslides with head scarps in the upper part of the } \\
\text { slopes and irregular, hummocky topography of the } \\
\text { landslide body }\end{array}$ & 3 & Upper-lower part & $\begin{array}{l}\text { Medium-high }(15-30 \mathrm{~m}) \\
\text { steep }\end{array}$ & & $\begin{array}{l}\text { Irregular, hummocky } \\
\text { topography, distinct toes }\end{array}$ & + \\
\hline
\end{tabular}


trench is widening, the surface of the upper part of the slope becomes undulated with shallow, elongated depressions and low ridges parallel to slope inclination (B2 type) (Fig. $10 \mathrm{~b}$ ). These ridges occur as a result of squeezing out plastic sedimentary rocks from below overlying rigid volcanic rocks. In the next stage a rocky bench slides down and gradually disintegrates (B3 type) (Fig. 10c). Then, a steep scarp remains at the crown of a landslide with some landslide relief present below (B4 type) (Fig. 10d). In the following stage the main scarps retreats through a series of shallow slides (B5 type). As a results only a short scarps can be found on the top of a mountain ridge with poorly visible remains of colluvial blocks below (Fig. 10e).

\section{Discussion}

The detailed analysis of landslide relief based on DEM from airborne LiDAR allowed to develop two main schemes of landslide evolution in the Kamienne Mts: (1) upslope, beginning at the base of a slope (Fig. 9) and (2) downslope, beginning from the top a mountain ridge (Fig. 10).

In the first scheme landsliding begins in the lower part of the slope, near the boundary between volcanic (latites or trachybasalts) and sedimentary rocks (mudstones and claystones) (Fig. 9a). The significant role in initiating landslides is played by fluvial erosion which leads to dissection of volcanic rocks and exposure of sedimentary rocks at the base of the slope. Otherwise, when the whole slope consists of volcanic rocks, it is stable and only small, shallow landslides may occur (Fig. 7 L1). Exposure of sedimentary rocks disturbs slope balance and causes the first event of landsliding. Landsliding at the base of slope additionally undermines slope stability which causes the landslide to expand upslope in subsequent events of landsliding. As a result landslide head scarps migrate towards mountain ridge (Figs. 7, 9). Eventually, the head scarp exceeds the topographic culmination of the mountain ridge, leading to its degradation. So far few schemes of upslope evolution of landslides have been described in literature. These type of schemes have been developed by e.g. Skempton (1953) for small catchments in the London Clay formation, Brooks et al. (2002) in New Zealand, Lévy et al. (2012) for Chacoura valley in Canada, Wistuba (2014) in the Hrubý Jeseník Mts and in the Moravskoslezské Beskydy Mts and Yenes et al. (2015) for Duero and Pisuerga valleys in Spain. However, these authors represents different views about the impact of landslides on the slope stability. Some of them claim that landsliding leads to increase of the slope stability (e.g. Skempton 1953; Brooks et al. 2002). The others maintain that the first landsliding episode precedes the next ones and contributes to the further instability of the slope, like in the Kamienne Mts (e.g Sánchez et al. 1999; Wistuba 2014; Yenes et al. 2015). However, as opposed to the Kamienne Mts, landslides expanding upslope, described so far in literature, usually develop in sedimentary rocks (Skempton 1953; Azañón et al. 2005; Lévy et al. 2012; Yenes et al. 2015). In the Kamienne Mts landslides are initiated by slow fluvial incision and lateral erosion, which lead to dissection of volcanic rocks covering plastic claystones and mudstones (Fig. 7 L2). Similar conception was presented by Yenes et al. (2015) on the case of landslides in Duero and Pisuerga valleys. The role of lateral erosion in landslide development was also emphasised by e.g. Skempton (1953), Palmquist and Bible (1980), Cendrero and Dramis (1996), Azañón et al. (2005), Lévy et al. (2012) and Wistuba (2014). Likewise in the Kamienne Mts, in the models devised by aforesaid authors a longlasting erosion initiate landsliding.

In the second scheme established in this paper landslides develop downslope (Fig. 10). It also begins at the boundary between volcanic (trachybasalts) and sedimentary rocks (mudstones and claystones), but in the 
uppermost part of the slope. Landslide trench occurs within rigid trachybasalts at the top of mountain ridge (Fig. 10a). Below plastic claystones and mudstones are deformed and squeezed out (Fig. $10 \mathrm{~b}$-c). The next stage is development and gradual disintegration of a rocky bench (Fig. 10d). Eventually, short scarps remain at landslide crown and retreat by subsequent slides of colluvial packets. Relief of the lower part of the slope becomes obliterated (Fig. 10e).

Landslides developing downslopes, which are described in literature, are usually vast Deep-Seated Landslides - a category of DeepSeated Gravitational Slope Deformations. DSGSDs are often found to completely reshape slopes in the high mountain areas and include many types of mass movements, e.g. lateral spreading and sagging (Pánek and Klimeš 2016).

Models of landslides expanding downslope, which are similar to scheme developed for the Kamienne Mts, are not widely described in literature. This kind of models were described by e.g. Bisci et al. (1996) in the Marche region in Italy, Zerathe and Lebourg (2012) in Maritime Alps and Migoń et al. (2013) for Mt Szczeliniec Wielki in the Stołowe Mts. In these schemes landsliding starts in the upper part of the slope, near the boundary between sedimentary rocks with different mechanical properties: sandstones and clays (Bisci et al. 1996), limestones with mudstones and gypsums (Zerathe and Lebourg 2012) or sandstones with claystones, mudstones and marls (Migoń et al. 2013). More resistant rocks usually form a cap in the uppermost part of the slope, likewise in the study area (Bisci et al. 1996; Migoń et al. 2013). Then, weak, ductile rocks are squeezed out under pressure of the overlayer (Migon et al. 2013) or outflow (Zerathe and Lebourg 2012). On the other hand, in the scheme proposed by Bisci et al. (1996) the rigid sandstone slabs float over the underlying clays. In the model by Migoń et al. (2013) squeezed plastic rocks form a distinctive transverse bulge, similar to ridges and depressions parallel to slope inclination in the Kamienne Mts (Fig. 8 B2-B3, Fig. 10 b-c). In addition, in both schemes subsidence affects the peripheral part of a trachybasaltic or sandstone slab. It effects with a widening trench and a sliding rocky bench in the Kamienne Mts or a sagging part of a table-topped hill of Mt Szczeliniec Wielki (Migoń et al. 2013). In the lower part of slopes the rigid rocks are degraded both in the Kamienne Mts and in the aforesaid models (Fig. 8 B4, Fig. 10d). This way clearly visible landslide bodies are formed (Bisci et al. 1996; Zerathe and Lebourg 2012; Migoń et al. 2013). Further evolution of landslides in the Kamienne Mts involves retreating of the head scarp by shallow sliding and leads to creating low scarps (Fig. 8 B5, Fig. 10e). Secondary scarps develop also in models described by Zerathe and Lebourg (2012) and Bisci et al. (1996).

In the Kamienne Mts consecutive landsliding episodes have been found able to almost completely degrade mountain ridges (Fig. 7 L6, Fig. 10e). The potential of landslides to reshaping topography to this extent is emphasized by e.g. Crozier (2010) and Korup et al. (2010). Analysis of a geological profile of the study area shows that mountain ridges of the Kamienne Mts are cuestas (Fig. 11). The faces of the escarpments are developed within latites (Włostowa Kostrzyna - Suchawa - Waligóra range) or trachybasalts (Klin - Turzyna - Jeleniec range). Escarpments are divided by depression moulded in mudstones and claystones. The majority of landslides outlined in the conducted study have been found on escarpments of cuestas facing northern directions (Figs. 3, 11). Only few develop on the cuesta backslopes, despite more favourable strike of strata. Thus its seems that landsliding in the study area is a mechanisms of cuesta escarpment retreat. The role of landslides in cuestas development is independent of the 


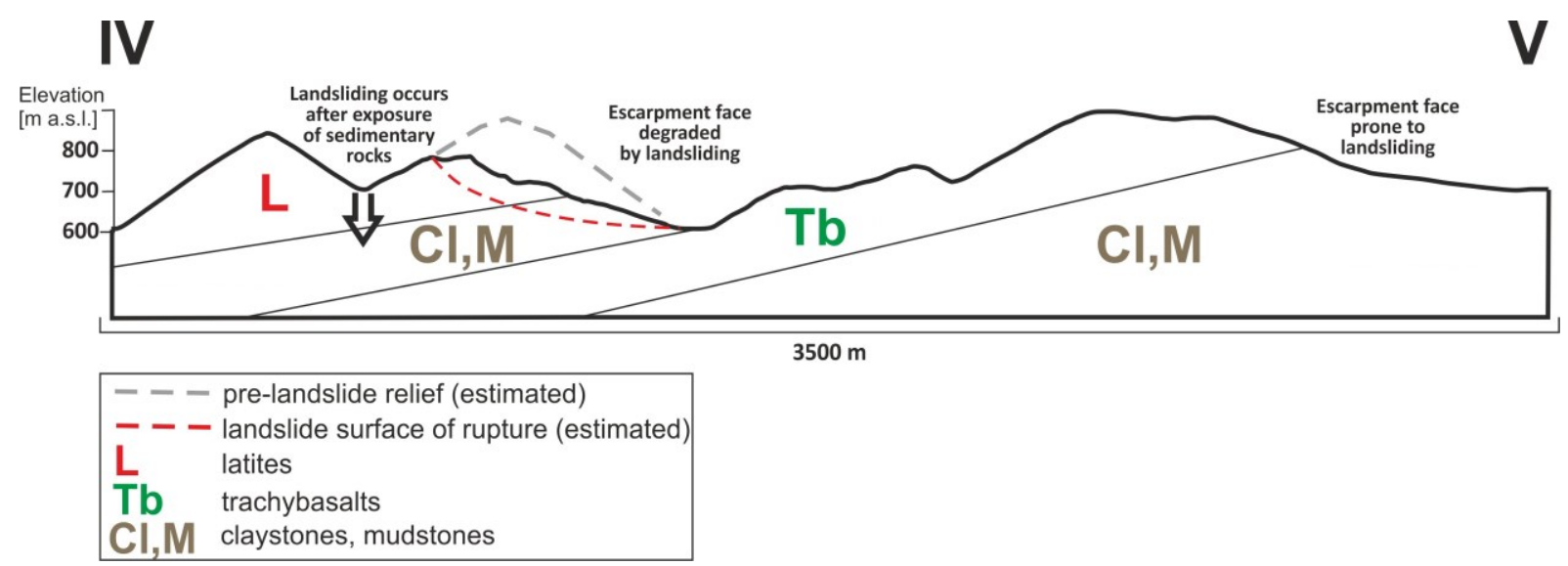

Fig.11. Cross section of the topography in the study area. The mountain ridges are cuestas developed in latites or trachybasalts divided by valleys developed in sedimentary rocks. Landsliding leads to cuesta faces retreat.

direction of landslides extension: upslope or downslope. In both schemes established in this paper landsliding is a factor significantly transforming slopes, leading to degradation of whole mountain ridges in advanced stages of relief development (Figs. 7-10).

\section{Conclusions}

- Landsliding is a common phenomenon in the Kamienne Mts. The major factor promoting mass movements in the study area is stratigraphical sequence of latites, trachybasalts and tuffs overlying claystones and mudstones. Landsliding is initiated near the boundary between volcanic and sedimentary rocks.

- Analysis of geological maps and a highresolution DEM from airborne LiDAR data allowed to distinguish characteristic types of landslide relief within different types of rocks: latites and trachybasalts. Established types represents consecutive stages of landslide slopes development.

- Two main schemes of landslide relief evolution were established: upslope and downslope. In the former landsliding starts at the base of a slope and develops upward. In the latter landsliding begins at the top of a mountain ridge and expands downward.

- The direction of relief development depends on the bedrock of a slope, in particular on the thickness of volcanic rocks in relation to underlying sedimentary rocks. When sedimentary rocks occur only in the lowest part of the slope, landslides develop upslope. When volcanic rocks form only a thin cap in the uppermost part of the slope landslides develop downslope. In both schemes landsliding leads to a significant transformation of slope relief, including degradation of the mountain ridges.

- The mountain ridges of the study area are cuestas and both described schemes of landslide development can be considered mechanisms causing retreat of cuesta escarpments.

\section{References}

Azañón J.M., Azor A., Pérez-Peña J.V., Carillo J.M. (2005) Late Quaternary large-scale rotational slides induced by river incision: The Arroyo de Gor area (Guadix basin, SE Spain). Geomorphology 69, 152-168, DOI: 10.1016/j.geomorph.2004.12.007

Bisci C., Burattini F., Dramis F., Leoperdi S., Pontoni F., Pontoni F. (1996) The Sant'Agata Feltria landslide (Marche Region, central Italy): a case of recurrent earthflow evolving from a deep-seated gravitational slope deformation. Geomorphology 15, 351-361, DOI: 10.1016/0169-555X(95)00080-O 
Bossowski A., Cymerman Z., Grocholski A., Ihnatowicz A. (1995) Explanations for detailed geological map of the Sudety Mts, Jedlina Zdrój sheet (Objaśnienia do Szczegółowej Mapy Geologicznej Sudetów, ark. Jedlina Zdrój). PIG, Warszawa (in Polish).

Brooks S.M., Crozier M.J., Preston N.J., Anderson M.G. (2002) Regolith stripping and the control of shallow translational hillslope failure: application of a twodimensional coupled soil hydrology-slope stability model, Hawke's Bay, New Zealand. Geomorphology 45, 165-179, DOI: 10.1016/S0169-555X(01)00153-2

Cendrero A., Dramis F. (1996) The contribution of landslides to landscape evolution in Europe. Geomorphology 15, 191-211, DOI: $\quad 10.1016 / 0169-$ 555X(95)00070-L

Clark M.K., Schoenbohm L.M., Royden L.H., Whipple K.X., Burchfiel B.C, Zhang X., Tang W., Wang E., Chen L. (2004) Surface uplift, tectonics, and erosion of eastern Tibet from large-scale drainage patterns. Tectonics 23, TC1006, DOI: 10.1029/2002TC001402

Crozier M.J. (2010) Landslide geomorphology: An argument for recognition, with examples from New Zealand. Geomorphology, 120, 3-15, DOI: 10.1016/j.geomorph.2009.09.010

Davis W.M. (1899) The geographical cycle. The Geographical Journal 14, 5, 481-504, DOI: $10.2307 / 1774538$

Gorczyca E. (2010) Slope relaxation following landslides in the Lososina River Basin, Beskid Wyspowy Mts., Poland. Landform Analysis 14, 3-11.

Gorczyca E., Krzemień K., Wrońska-Wałach D., Boniecki M. (2014) Significance of extreme hydro-geomorphological events in the transformation of mountain valleys (Northern Slopes of the Western Tatra Range, Carpathian Mountains, Poland).
Catena 121, 127-141, DOI: 10.1016/j.catena.2014.05.004

Grocholski A. (1972) Landslide traces on the slopes of Lesista Wielka Mt in the Kamienne Mts (Ślady osuwisk na stokach Lesistej Wielkiej w Górach Kamiennych). Polskie Towarzystwo Miłośników Nauk o Ziemi, Koło Górnicze w Gorcach, Biuletyn Informacyjny, 11, 9-14 (in Polish)

Guglielmi Y., Cappa F. (2010) Regional-scale relief evolution and large landslides: Insights from geomechanical analyses in the Tinée Valley (southern French Alps). Geomorphology 117, 121-129, DOI: 10.1016/j.geomorph.2009.11.016

Jaboyedoff M., Oppikofer T., Abellán A., Derron M.-H., Loye A., Metzger R., Pedrazzini A. (2012) Use of LIDAR in landslide investigations: a review. Nat Hazards 61, 5-28, DOI: 10.1007/s11069010-9634-2

Kasprzak M., Duszyński F., Jancewicz K., Michniewicz A., Różycka M., Migoń P. (2016) The Rogowiec Landslide Complex (Central Sudetes, SW Poland)- a case of a collapsed mountain. Geological Quaterly 60, 3, 695-713, DOI: 10.7306/gq.1286

Kasprzak M., Traczyk A. (2012) Conditiong of landslides development in central part of the Kamienne Mountains (Sudetes). Landform Analysis 20, 65-77.

Kirby E., Whipple K.X., Tang W., Chen Z. (2003) Distribution of active rock uplift along the eastern margin of the Tibetan Plateau: inferences from bedrock channel longitudinal profiles. Journal of Geophysical Research 108, B4, 2217, DOI: 10.1029/2001JB000861

Klimaszewski M. (1967) Development of granite slopes in the high mountain areas in the late Glacial and Holocene times. Guide to excursion of the Symposium of the Commission on the Evolution of Slopes and of the Commission on Periglacial Geomorphology of the IGU, Poland, September 1967. 
Korup O., Densmore A.L., Schlunegger F. (2010) The role of landslides in mountain range evolution. Geomorphology 120, 7790, DOI: 10.1016/j.geomorph.2009.09.017

Kotarba A. (1986) The role of landslides in modelling of the Beskidian and Carpathian Foothills relief. Przegląd Geograficzny 58, 1-2, 119-129.

Lavé J., Avouac J.P. (2001) Fluvial incision and tectonic uplift across the Himalayas of central Nepal. Journal of Geophysical Research 106, B1, 26561-26591, DOI: 10.1029/2001JB000359

Lévy S., Jaboyedoff M., Locat J., Demers D. (2012) Erosion and channel change as factors of landslides and valley formation in Champlain See Clays: The Chacoura River, Quebec, Canada. Geomorphology 145-146, 12-18, DOI: 10.1016/j.geomorph.2011.09.014

Migoń P. (2010) New data for recognition of the landslide relief of Kamienne Mts (Nowe dane do poznania rzeźby osuwiskowej Gór Kamiennych). Przyroda Sudetów 13, 215-224 (in Polish).

Migoń P., Jancewicz K., Kasprzak M. (2014a) The extent of landslide-affected areas in the Kamienne Mountains (Midlle Sudetes) - a comparison of geological maps and a LiDAR based digital elevation model. Przegląd Geologiczny 62, 9, 463-470.

Migoń P., Kacprzak A., Malik I., Kasprzak M. (2014b) Landslide geomorphology of the Kamienne Mountains (Middle Sudetes) criteria of identification and hazard assessment. Landform Analysis 26, 39-60, DOI: $10.12657 /$ landfana.026.004

Migoń P., Kacprzak A., Malik I., Kasprzak M., Owczarek P., Wistuba M., Pánek T. (2014c) Geomorphological, pedological and dendrochronological signatures of a relict landslide terrain, Mt Garbatka (Kamienne Mts), SW Poland. Geomorphology 219, 213-231, DOI: 10.1016/j.geomorph.2014.05.005
Migoń P., Kasprzak M., Traczyk A. (2013) How high-resolution DEM based on airborne LiDAR helped to reinterpret landforms - examples from the Sudetes, SW Poland. Landform Analysis 22, 89101, DOI: 10.12657/landfana.022.007

Migoń P., Pánek T., Malik I., Hrádecký J., Owczarek P., Šilhán K. (2010) Complex landslide terrain in the Kamienne Mountains, Middle Sudetes, SW Poland. Geomorphology 124, 200-214, DOI: 10.1016/j.geomorph.2010.09.024

Palmquist R.C., Bible G. (1980) Conceptual modelling of landslide distribution in time and space. Bulletin of the International Association of Engineering Geology 21, 178-186, DOI: 10.1007/BF02591559

Pánek T., Klimeš J. (2016) Temporal behavior of deep-seated gravitational slope deformations: A review. Earth-Science Reviews 156, 14-38, DOI: 10.1016/j.earscirev.2016.02.007

Pánek T., Mentlík P., Engel Z., Braucher R., Zondervan A. (2017) Large Quaternary sackungen in the highest mountains of the Carpathians. Quaternary Science Reviews 159, 47-62, DOI: 10.1016/j.quascirev.2017.01.008

Penck W. (1953) Morphological Analysis of Landforms. Translated by Czech $\mathrm{H}$. and Boswell K. C., Macmillan, London.

Pulinowa M.Z. (1972) Landsliding in artificial and natural environment (Procesy osuwiskowe $\mathrm{w}$ środowisku sztucznym i naturalnym). Dokumentacja Geograficzna IG PAN 4, Warszawa (in Polish).

Pulinowa M.Z., Mazur R. (1971) An old landslide in the Grzmiaca village in the Sudetes (Stare osuwisko we wsi Grzmiąca w Sudetach). Wszechświat 7-8, 200-202 (in Polish).

Sánchez M.J., Farias P., Rodríguez A., Duarte R.A.M. (1999) Landslide development in a coastal valley in the Northern Spain: conditioning factors and temporal 
occurrence. Geomorphology 30, 115-123, DOI: 10.1016/S0169-555X(99)00048-3

Schwartz S., Zerathe S., Jongmans D., Baillet L., Carcaillet J., Audin L., Dumont T., Bourlès D., Braucher R., Lebrouc V. (2017) Cosmic ray exposure dating on the large landslide of Séchilienne (Western Alps): A synthesis to constrain slope evolution. Geomorphology 278, 329-344, DOI: 10.1016/j.geomorph.2016.11.014

Shroder Jr. J.F., Owen L.A., Seong Y.B., Bishop M.B., Bush A., Ceffee M.W., Copland L., Finkel R.C., Kamp U. (2011) The role of mass movements on landscape evolution in the Central Karakoram: Discussion and speculation. Quaternary International 236, 34-47, DOI: 10.1016/j.quaint.2010.05.024

Skempton A.W. (1953) Soil mechanics in relation to geology. Proceedings of the Yorkshire Geological Society 29, 3, 33-62, DOI: $10.1144 /$ pygs.29.1.33

Skempton A.W., Delory F.A. (1957) Stability of natural slopes in London Clay. Proceedings of the Fourth International Conference on Soil Mechanics and Foundation Engineering, Mexico, 291-340, DOI: $10.1680 /$ sposm. 02050.0011

Snyder N.P., Whipple K.X., Tucker G.E., Merritts D.J. (2003) Channel response to tectonic forcing: field analysis of stream morphology and hydrology in the Mendocino triple junction region, northern California. Geomorphology 53, 97-127, DOI: $10.1016 / \mathrm{S} 0169-555 \mathrm{X}(02) 00349-5$

Starkel L. (1960) The development of the Flysch Carpathians relief during the Holocene (Rozwój rzeźby Karpat fliszowych w holocenie). Prace Geograficzne 22, Instytut Geografii PAN, Warszawa (in Polish)
Synowiec G. (2003) Landslides in the Kamienne Mts, Sudetes (SW Poland). Przegląd Geologiczny 51, 1, 59-65.

Varnes D.J. (1978) Slope Movement Types and Processes. [In:] Special Report 176:Landslides:Analysis and Control (ed. R.L. Schuster, R.J. Krizek). Transportation and Road Research Board, National Academy of Science, Washington D.C., 11-33.

Wistuba M. (2014) Slope-Channel Coupling as a Factor in the Evolution of Mountains. The Western Carpathians and the Sudetes. Springer Theses. DOI: 10.1007/978-3-31905819-1

Wistuba M., Malik I., Wójcicki K., Michałowicz P. (2015) Coupling between landslides and eroding stream channels reconstructed from spruce tree rings (examples from the Carpathians and Sudetes - Central Europe). Earth Surface Processes and Landforms 40, 293-312, DOI: $10.1002 /$ esp. 3632

Yenes M., Monterrubio S., Nespereira J., Santos G., Fernández-Macarro B. (2015) Large landslides induced by fluvial incision in the Cenozoic Duero Basin (Spain). Geomorphology 246, 263-276, DOI: 10.1016/j.geomorph.2015.06.022

Zerathe S., Lebourg T. (2012) Evolution stages of large deep-seated landslides at the front of a subalpine meridional chain (MaritimeAlps, France). Geomorphology 138, 390403, DOI: 10.1016/j.geomorph.2011.10.006

Ziętara T. (1974) The role of landslides in modelling the Rożnów Foothills (Western Flysch Carpathians) (Rola osuwisk w modelowaniu Pogórza Rożnowskiego (Zachodnie Karpaty fliszowe). Studia Geomorph. Carpatho-. Balcanica 8, 115133 (in Polish). 